\title{
Path Exploration of Integrating Ideological and Political Elements into the Teaching of "Biomass Power Generation Engineering"
}

\author{
Nan Wu ${ }^{a}$, Dengchao Jin ${ }^{b}$, Xinyuan Liu ${ }^{c}$, Jinxing Peng ${ }^{d}$, Li Wang e, * \\ College of Engineering and Technology, Tianjin Agricultural University, Tianjin 300392, China \\ a nwu@tjau.edu.cn, b328565059@qq.com, c liuxinyuan11@163.com, d397024587@qq.com, \\ e, "wanglimay@163.com
}

\begin{abstract}
Curriculum ideological and political education is not only an important way for the education reform in colleges and universities, but also the internal requirement for the fundamental task of building morality and cultivating students. Biomass power generation engineering is an essential and featured professional course of new energy science and engineering major. Taking the course teaching of "biomass power generation engineering" as an example, this study analyzed the necessity of carrying out the ideological and political education, and explored the top-level design scheme of the curriculum ideological and political education and the trinity educational objectives. Meanwhile, the ways of mutual integration of ideological and political elements and professional knowledge points were discussed, and the curriculum teaching reform and practical exploration were carried out, so that the ideological and political education could run throughout the whole process of course learning. The purpose is to provide reference for the ideological and political teaching of science and engineering courses.
\end{abstract}

Keywords: Curriculum Ideology and Politics; Practice Teaching; New Energy; Engineering Course.

\section{Introduction}

Since the 18th National Congress of the Communist Party of China, a series of important meetings such as the national conference on ideological and political work in colleges and universities have been held successively, emphasizing the necessity of strengthening ideological and political education in Chinese colleges and universities. Curriculum ideological and political education means that colleges and universities run through the ideological, political and moral quality education in various education links, including curriculum content, classroom teaching, practical teaching and the second classroom. By means of classroom penetration, we should constantly tap the ideological and political elements in the curriculum system, in order to realize the goal of building morality and comprehensively cultivating talents in the new era [1-2]. The ideological and political education is not rigidly incorporated into the ideological and political contents, but intends to excavate the organic integration point of ideological and political education during the professional courses teaching process [3]. The purpose of "moral and intellectual parallelism" can be realized by enriching and innovating teaching methods, as well as conducting in-depth teaching.

Biomass power generation engineering is an essential and featured professional course of new energy science and engineering major. This paper intends to focus on how to carry out curriculum ideological and political education in the course of "biomass power generation engineering". Combined with the characteristics of agricultural colleges and universities, the moral education elements in the course of biomass power generation engineering were excavated and summarized. That also provided a reference for "three" education in the classroom teaching of other science and engineering courses, to achieve value leading education. 


\section{Necessity of Carrying out Ideological and Political Education in Biomass Power Generation Engineering}

At present, the world is in a period of great change and adjustment, various social ideological trends are surging. Students in colleges and universities are in an ideological and consciousness growth period, and their abilities to distinguish new ideas and new things are not mature enough. So, students are easy to be bewitched by bad ideas. In addition, under the long-term thinking mode of science and engineering, students' logical thinking abilities are strengthened, but they are indifferent to the abstract social theory and have fewer social feelings [2-3]. What's worse, some students may have the thoughts of "pragmatism" and "egoism". Therefore, it is necessary to strengthen ideological and political education, and to guide students to establish a correct world outlook, outlook on life and values, as well as to stimulate students' feelings and mission of serving the country through science and technology.

\section{Top Level Design of Ideology and Politics in Biomass Power Generation Engineering}

The implementation of curriculum ideological and political education is not an island education model, but a continuous and intensive process. We should strengthen the "top-level design" and overall planning for the course [3-4]. While paying attention to the top-level design, we should also take into account the professionalism and interest of contents, and turn the classroom into the carrier of ideological and political education. The course of biomass power generation engineering adheres to the educational concept of cultivating applied talents who serve agriculture, rural areas and farmers, and have craftsmen spirit in the new era (Fig. 1). To improve the abilities of students' innovative thinking and solve complex problems, we follow students' cognitive laws and build a "learning by doing, modularization and step-by-step" teaching content system. The breadth and depth of teaching content are expanded to realize the cross integration of multiple disciplines.

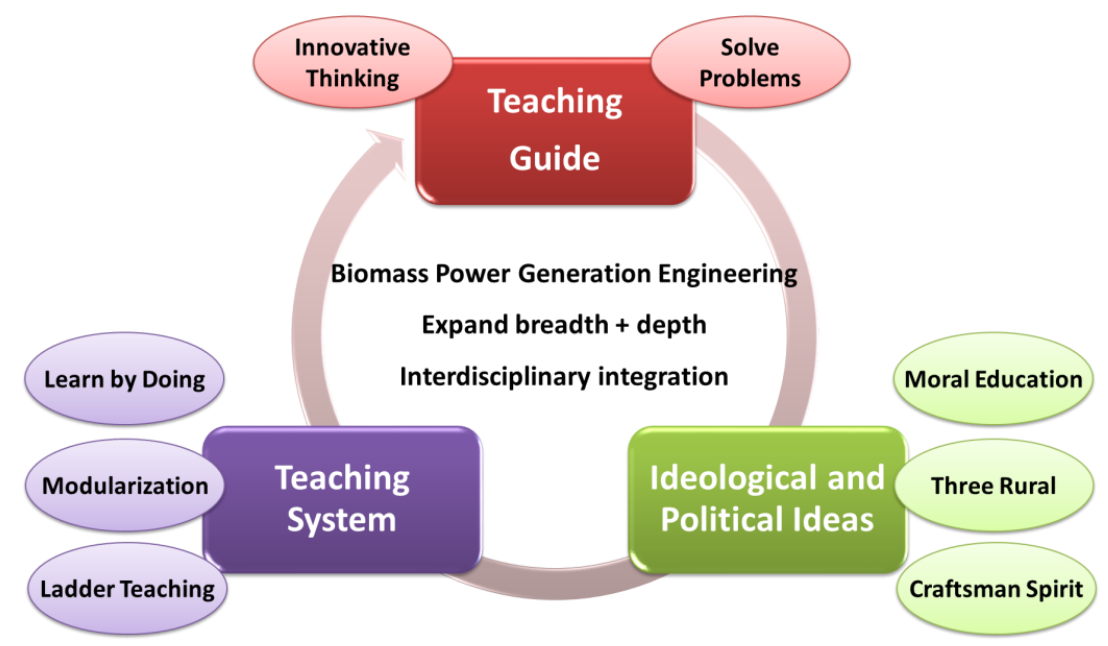

Fig 1. Overall teaching concept of "Biomass Power Generation Engineering"

The promotion of curriculum ideological and political construction emphasizes that values are guided in knowledge teaching and ability training, so as to help students shape a correct world outlook, life outlook and value outlook [5-6]. Combined with students' characteristics and the orientation and graduation requirements of our university, we have formulated the "Trinity" aim of curriculum (Fig. 2). (i) Knowledge level: students were expected to remember the relevant principles and equipment process design of biomass combustion, gasification and power generation; Master the calculation of mass energy conservation in the process of biomass combustion. (ii) Ability level: enable students to select, develop and design biomass power generation and other related equipment combining with 
actual situation; Formulate innovative and diversified pollutant prevention and treatment schemes; Track the cutting-edge technologies of biomass energy and solve complex engineering problems in this field. (iii) Ideological and political level: cultivate students' feelings of "agriculture, rural areas and farmers" by integrating the concept of green environmental protection and craftsman spirit of excellence into teaching content, and stimulate students' spirit of responsibility for improving China's rural energy structure and the innovative development of biomass energy.

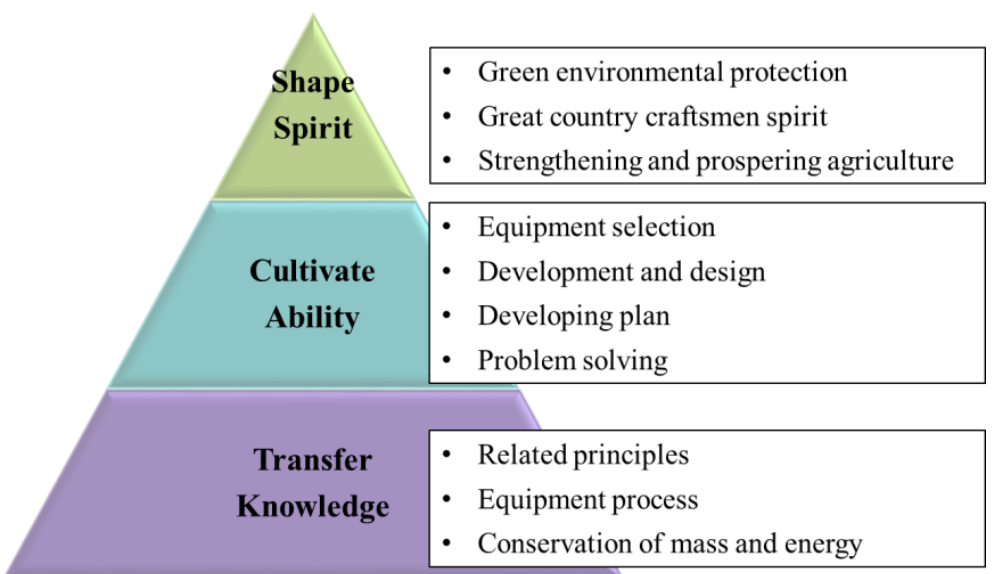

Fig 2. Trinity aims of "Biomass Power Generation Engineering"

\section{Practical Cases of Ideological and Political Education in the Course of Biomass Power Generation Engineering}

The teaching content of biomass power generation engineering can be generally divided into seven knowledge units. Around the goal of ideological and political education, the ideological and political education resources contained in each knowledge unit are analyzed and excavated, and the key ideological and political points are refined (Table 1). Moreover, appropriate classroom model is used to run the curriculum ideological and political education throughout the classroom teaching. For example, the methods of enumerating cases and people's deeds were adopted to ensure that students could accept and recognize the ideological and political ideas conveyed by teachers to the greatest extent.

Table 1. The main knowledge units of "Biomass Power Generation Engineering" and the corresponding key points of ideological and political teaching

\begin{tabular}{|c|c|}
\hline Knowledge units & Ideological and political teaching points \\
\hline Introduction & $\begin{array}{l}\text { Materialist dialectical world outlook, scientific outlook on development, } \\
\text { ecological civilization concept }\end{array}$ \\
\hline $\begin{array}{l}\text { Pretreatment of biomass raw } \\
\text { materials }\end{array}$ & $\begin{array}{l}\text { Emphasize the importance and necessity of clean and efficient utilization } \\
\text { of energy }\end{array}$ \\
\hline Biomass combustion chemistry & $\begin{array}{c}\text { Strengthen the thinking ability of "seeing the essence through the } \\
\text { phenomenon" }\end{array}$ \\
\hline Biomass combustion equipment & $\begin{array}{l}\text { Emphasize the craftsman spirit, environmental protection consciousness } \\
\text { and innovation consciousness of scientific research workers }\end{array}$ \\
\hline $\begin{array}{l}\text { Biomass direct combustion / } \\
\text { mixed combustion power } \\
\text { generation }\end{array}$ & $\begin{array}{l}\text { Improve students' senses of mission to realize clean, efficient and safe } \\
\text { utilization of energy }\end{array}$ \\
\hline $\begin{array}{l}\text { Waste incineration power } \\
\text { generation }\end{array}$ & $\begin{array}{l}\text { Adhere to the concept of resource conservation and environmental } \\
\text { protection, green life and development; waste free city; sense of } \\
\text { responsibility and innovation }\end{array}$ \\
\hline $\begin{array}{l}\text { Biomass gasification power } \\
\text { generation }\end{array}$ & Professionalism, craftsmanship, environmental protection and innovation \\
\hline
\end{tabular}


Volume 3 (2021)

\section{Summary}

Under the complex background of the interweaving and infiltration of social diversified values, the limitations of relying solely or excessively on ideological and political courses are becoming increasingly prominent to guide the values of students in universities or colleges. It is urgent to give full play to the advantages of multi-disciplinary and all-round education. We should integrate ideological and political education into all the links and aspects of professional curriculum teaching and reform, to build morality, to cultivate people and to nourish in silence. We need to unremittingly guide college students to firmly establish socialist core values. As well we should work with students to become firm believers, active communicators and model practitioners of socialist core values.

\section{Acknowledgments}

This research was supported by Educational and Teaching Reform Project of Tianjin Agricultural University (2018-B-34) and Tianjin Enterprise Science and Technology Commissioner Project (20YDTPJC01880).

\section{References}

[1] Wang ZY, Wang Y, Ji ZC. Ideological and political teaching reform of power electronic technology for new engineering. Journal of higher education. 35 (2020) 140-143.

[2] Shen JY, Chai W, Li QY, et al. Exploration and practice of curriculum thought and politics in the teaching of engineering chemistry. Guangdong chemical industry. 47 (2020) 242-244.

[3] Wu XP. Mining the ideological and political elements of university science and engineering courses. Journal of Yangzhou University (Higher Education Study Edition). 24 (2020) 81-85.

[4] Sun QY, Huang YJ, Gao JW. Ideological and political construction scheme of engineering professional courses--Taking the course of power system analysis as an example. Proceedings of the CSEE. 2 (2021) 475-485.

[5] Gao WR, Ma HH. Teaching of principle and technology of biomass energy conversion. Guangdong chemical industry. 47 (2020) 226-227.

[6] Huang ZH, Sun XY, Li JS, et al. Teaching exploration of integrating ideological and political elements into practical courses of environmental engineering specialty. University Education. 10 (2020) 155-157. 